\title{
Mercury accumulation in adults of two large species of diving beetles (Coleoptera: Dytiscidae)
}

\section{Накопление ртути у имаго двух крупных видов жуков-пиавунџов (Coleoptera: Dytiscidae)}

\author{
Yu.G. Udodenko ${ }^{1,2}$, D.G. Seleznev ${ }^{1}$, A.A. Prokin ${ }^{1,2}$, E.S. Ivanova ${ }^{2}$, \\ A.I. Zemlyanukhin ${ }^{3}$ \\ Ю.Г. УАоденко ${ }^{1,2}$, А.Г. Селезнев ${ }^{1}$, А.А. Прокин ${ }^{1,2}$, Е.С. Иванова ${ }^{2}$, \\ А.И. Землянухин
}

\footnotetext{
${ }^{1}$ Papanin Institute for Biology of Inland Waters, Russian Academy of Sciences, Borok, Nekouzsky District, Yaroslavl Oblast 152742, Russia.

${ }^{1}$ Институт биологии внутренних вод им. И.Д. Папанина РАН, Борок, Некоузский р-н, Ярославская область 152742, Россия.

${ }^{2}$ Cherepovets State University, Lunacharskogo 5, Cherepovets, Vologda Oblast 162600, Russia.

2 Череповецкий государственный университет, пр-т Луначарского, Череповец, Вологодская область 162600, Россия.

${ }^{3}$ Semenov-Tian-Shansky Lipetsk State Pedagogical University, Lenina 42, Lipetsk 398020, Russia.

3 Липецкий государственный педагогический университет им. П.П. Семёнова-Тян-Шанского, ул. Ленина 42, Липецк 398020 , Россия.
}

KEY WORDS: mercury, accumulation, Dytiscidae, Dytiscus, Cybister, body parts, males, female morphs. КЛЮЧЕВЫЕ СЛОВА: ртуть, накопление, Dytiscidae, Dytiscus, Cybister, части тела, самцы, формы самок.

ABSTRACT. We have analyzed mercury accumulation in different body parts of two species of diving beetles (Coleoptera, Dytiscidae), Dytiscus circumcinctus and Cybister lateralimarginalis. We have estimated the difference in mercury accumulation for these species and determined the sufficient representative sample. We have revealed broad range of a set of data for $C$. lateralimarginalis and statistically significant differences in median values of the mercury accumulation between the two species. The differences in median values between species are greater in males than in females; the average values of the data set are equal. The averages of the mercury concentrations in body parts decline in the following order: meso-, metathorax, and abdomen $>$ legs $>$ head and prothorax $>$ elytra and wings. Significant differences in averages of the mercury concentration have been recorded for different female morphs of $D$. circumcinctus: the mercury concentration in smooth females is higher than in sulcate females, which is determined by the higher mercury concentration in meso-, metathorax, and abdomen.

РЕЗЮМЕ. Проанализировано накопление ртути в различных частях тела двух видов плавунцов (Coleoptera, Dytiscidae) - Dytiscus circumcinctus и Cybister lateralimarginalis. Определена величина эффекта разницы в накоплении ртути и необходимый для его фиксирования объём выборок. Установлены статистически значимые различия медиан накопления ртути между видами и больший разброс значений у C. lateralimarginalis. Межвидовые различия медиан выражены сильнее у самцов, чем у самок при одинаковых средних значениях. Среднее содержание ртути в частях тела снижается в ряду: “средне- и заднегрудь+брюшко”>ноги>”голова и переднегрудь”>”надкрылья и крылья". Достоверные различия средней концентрации ртути отмечены между самками разных морф D. circumcinctus: у гладких самок концентрации ртути достоверно выше, чем у ребристых, что определяется концентрацией ртути в “средне- и заднегрудь+брюшко”.

\section{Introduction}

Mercury is a heavy metal element, which toxic compounds exert biological effects [Fitzgerald, Lamborg, 2007]. It can be accumulated in the body, impair organ functionality, and even threaten the survival [Scheuhammer et al., 2015]. Mercury is emitted into the atmosphere as a result of natural processes (eruptions of volcanoes and evaporation from the ocean surface) and

How to cite this article: Udodenko Yu.G., Seleznev D.G., Prokin A.A., Ivanova E.S., Zemlyanukhin A.I. 2019. Mercury accumulation in adults of two large species of diving beetles (Coleoptera: Dytiscidae) // Russian Entomol. J. Vol.28. No.1. P.23-29. doi: 10.15298/rusentj.28.1.04 
human activities (use of fossil fuel, metallurgic and chemical industry etc.), and it is transported by airflow over large distance and deposited far away from the emission sources [Selin, 2009]. Mercury levels rise in organisms according to their trophic level: the highest levels within local trophic networks are found in carnivorous animals [Mergler et al., 2007; Rice et al., 2014].

Both adult and larval predaceous diving beetles (Dytiscidae) are active predators, and they can become apex predators in waterbodies where fish is absent [Arnott et al., 2006]. The highest diversity of food sources is recorded for the largest individuals of the subfamily Dytiscinae, with the genera Dytiscus and Cybister present in the Palearctic.

The native range of Cybister lateralimarginalis (De Geer, 1774) covers North Africa, Southern and Central Europe, Western and Central Asia, Mongolia, China, North India, and the species range is actively expanding to the north in European Russia, where it was observed in Leningrad and Pskov Oblasts [Litovkin, Sazhnev, 2016; Prokin, Cherevichko, 2017]. It is important to determine mechanisms of adaptations that lead to a successful species expansion, and it may have practical applications in the future.

Data on the accumulation of heavy metals in Dytiscidae, including mercury, are scarce [Zhulidov, Emets, 1981; Hothem et al., 2011]. Any data on the metal distribution in different body parts of the beetles are lacking. Mercury accumulation in different female morphs (reticulate, sulcate, and smooth) of the family Dytiscidae has not been studied before. The presence of morphs allows females to reach a compromise between reproductive success and survival after mating [Bergsten et al., 2001], and the difference in accumulation of heavy metals, including mercury, is of interest in this light.

Our publication is based on preliminary data that were analyzed earlier [Prokin et al., 2018]. It was shown that the sex ratio $\left(\sigma^{\top} / 9\right)$ in winter was 0.60 in Cybister lateralimarginalis and 1.73 in Dytiscus circumcinctus Ahrens, 1811. The average wet weight of C. lateralimarginalis females was significantly higher than in males, and there were no significant differences in the weights of $D$. circumcinctus males and females. The number of reticulate females was an order of magnitude greater than smooth females in the population of $C$. lateralimarginalis, and the number of sulcate females was only 1.6 times as great as the number of smooth females in $D$. circumcinctus. We suggested that the predominance of reticulate females in the population of $C$. lateralimarginalis than sulcate females in D. circumcinctus was one of the mechanisms that ensure the expansion of the species range to the north [Prokin et al., 2018].

The aim of our study is to determine the mercury content in different body parts of the large predaceous diving beetles $C$. lateralimarginalis and $D$. circumcinctus in winter, which allows us to be certain that the studied specimens were actively feeding during at least one season and the mercury concentration in their bodies corresponded with their trophic level. We focus on the specifics of the mercury accumulation in both sexes and in all female morphs.

\section{Material and methods}

A. I. Zemlyanukhin collected specimens of C. lateralimarginalis and D. circumcinctus with koshura (willow traps for fish) on February 2017 in the oxbow lake Treshchevka in the Voronezh River floodplain, Lipetsk Oblast, Russia. A total of 267 specimens of C. lateralimarginalis and 126 specimens of D. circumcinctus have been studied. Prokin et al. [2018] have described methods of collecting the beetles, and analyzed the sex structure and correlation of the weight in males and different female morphs of the studied populations.

Mercury concentration in beetle specimens was determined using a PA-915 Hg analyzer equipped with a PIRO attachment (Lumex, Russia) in the Papanin Institute for Biology of Inland Waters, Russian Academy of Sciences, Borok, Russia. The accuracy of the analytical method was controlled using certified reference materials DORM-2 and DOLM-2 in the Institute of Environmental Chemistry, Ottawa, Canada. Before the analysis, the insects were dried in an oven for 48 hours at $25^{\circ} \tilde{\mathrm{N}}$. Mercury content was measured in the following clusters of body parts: (1) legs, (2) head and prothorax (pronotum), (3) elytra and wings, (4) meso-, metathorax, and abdomen. The mercury content (Hgs) per specimen was calculated based on the following formula:

$\operatorname{Hgs}=(\operatorname{Hga} \times \mathrm{A})+(\operatorname{Hgb} \times \mathrm{B})+(\operatorname{Hgc} \times \mathrm{C})+(\operatorname{Hgd} \times \mathrm{D}) / 100$,

where $\mathrm{Hga}, \mathrm{Hgb}, \mathrm{Hgc}, \mathrm{Hgd}$ are the mercury contents in body parts $[\mu \mathrm{g} / \mathrm{g}$ of the dry weight (d.w.)]; A, B, C, D are the average weight fractions of body parts per weight of specimen $(\%)$. These values are the average weight proportions of body parts in the dry weight of separate specimens from an unbiased sample of 5 males and different female morphs of each species (Table 1).

Power analysis for a two-sample t-test was used to estimate the sufficient sample size. P-value was 0.05 , power was 0.9 , the effect size was calculated as $\mathrm{d}=\left(\mid \mathrm{m}_{1}-\right.$ $\left.\mathrm{m}_{2} \mid\right)$ /sd and was 0.24 , where $\mathrm{m}_{1}$ and $\mathrm{m}_{2}$ are the sample means, and sd is the pooled within sample standard deviation [Cohen, 1988]. The sufficient sample size was 359 samples for each species, the amount that is 1.3-2.8 times greater than the one we had.

We did not achieve conditions of the normal distribution (Shapiro-Wilk test) and sufficient sample size. Therefore, the comparison of two groups was performed using the Fisher-Pitman permutation test for independent samples with 10000 permutations [Hollander, Wolfe, 1999], and for several groups using permutational analysis of variance with 100000 permutations. Multiple comparisons were corrected using the Bonferroni correction.

Calculations were performed in R 3.3 statistical analysis environment using the packages "rcompanion", "pwr", "coin", and "lmPerm". The initial data set and R code can be downloaded from http://www.ibiw.ru/ upload/staff/267/dytiscidae2.zip 
Table 1. Average weight proportions (\%) of different body parts per weight of specimen Таблица 1. Средняя доля (\%) различных отделов тела в массе одной особи

\begin{tabular}{|c|c|c|c|c|c|}
\hline \multirow[b]{2}{*}{ species } & \multirow[b]{2}{*}{ sex, morph } & \multicolumn{4}{|c|}{$\%$ of body weight } \\
\hline & & $\begin{array}{l}\text { elytra and } \\
\text { wings }(A)\end{array}$ & $\begin{array}{c}\text { head and } \\
\text { prothorax (B) }\end{array}$ & legs $(C)$ & $\begin{array}{c}\text { meso-, } \\
\text { metathorax and } \\
\text { abdomen (D) }\end{array}$ \\
\hline \multirow{3}{*}{ C. lateralimarginalis } & 90, smooth & 12 & 12 & 12 & 64 \\
\hline & 90 , reticulate & 18 & 13 & 9 & 60 \\
\hline & $0^{7} 0^{x}$ & 19 & 13 & 14 & 54 \\
\hline \multirow{3}{*}{ D. circumcinctus } & $\begin{array}{l}00, \text { smooth } \\
++, \text { s. }\end{array}$ & 15 & 9 & 16 & 60 \\
\hline & 90 , sulcate & 15 & 8 & 16 & 61 \\
\hline & $0^{7} 0^{7}$ & 14 & 18 & 9 & 59 \\
\hline
\end{tabular}

\section{Results}

The average dry weight of $C$. lateralimarginalis is significantly lower than that of $D$. circumcinctus $(\mathrm{Z}=-$ 7.69, p $\ll 0.001)$ (Fig. 1). Previously we revealed significant differences in the wet weight between sexes of $C$. lateralimarginalis, but the dry female weight was significantly higher than dry male weight in both species $(Z=9.4, \mathrm{p} \ll 0.001$ and $Z=5.54, \mathrm{p} \ll 0.001$ respectively) (Table 2). Furthermore, we have determined significant differences in the dry weight of females with different elytral surfaces in C. lateralimarginalis $\left(\chi^{2}=92 ; p \ll 0.001\right)$, but the dry weight of different female morphs of each species showed no significant differences. Female and male specimens of C. lateralimarginalis have significant differences in the dry weight dispersion than the ones of $D$. circumcinctus (Levene's test: $\mathrm{f}=15.66, \mathrm{p}<0.001 ; \mathrm{f}=20.6$, $\mathrm{p} \ll 0.001$ respectively).

Averages of the mercury concentration in C. lateralimarginalis and in $D$. circumcinctus were $0.220 \pm 0.155$ (here and later average $\pm \mathrm{SD}$ ) $\mu \mathrm{g} / \mathrm{g} \mathrm{d} . \mathrm{w}$. and
$0.254 \pm 0.094 \mu \mathrm{g} / \mathrm{g}$ d.w., median values were 0.189 and 0.237 respectively.

Permutational tests show no significant differences of the average mercury concentration in species $(Z=-$ $1.565, \mathrm{p}=0.119)$. Nevertheless, rank tests show significant differences in median values (the KruskalWallis test: $\left.\chi^{2}=17.6, \mathrm{p} \ll 0.001\right)$ and central tendencies, which are close to median values (the MannWhitney test: $\mathrm{W}=12441, \mathrm{p} \ll 0.001)$. It is explained by the abnormally high mercury concentrations $(>0.7)$ in several specimens of $C$. lateralimarginalis, which shifts the mean value relative to the median concentration (Fig. 2).

The median values of the mercury concentration are higher in D. circumcinctus males and females separately (in males with $\mathrm{W}=2735.5, \mathrm{p}<0.001$, the differences are larger than in females with $\mathrm{W}=3114.5, \mathrm{p}=0.049)$. Average values show no significant difference. Variance of the mercury concentration in C. lateralimarginalis is higher than in D. circumcinctus (Levene's test: $\mathrm{f}=10.65, \mathrm{p}=0.001$; Fig. 3 ). Variance of the mercury concentration is higher in $C$. lateralimarginalis females
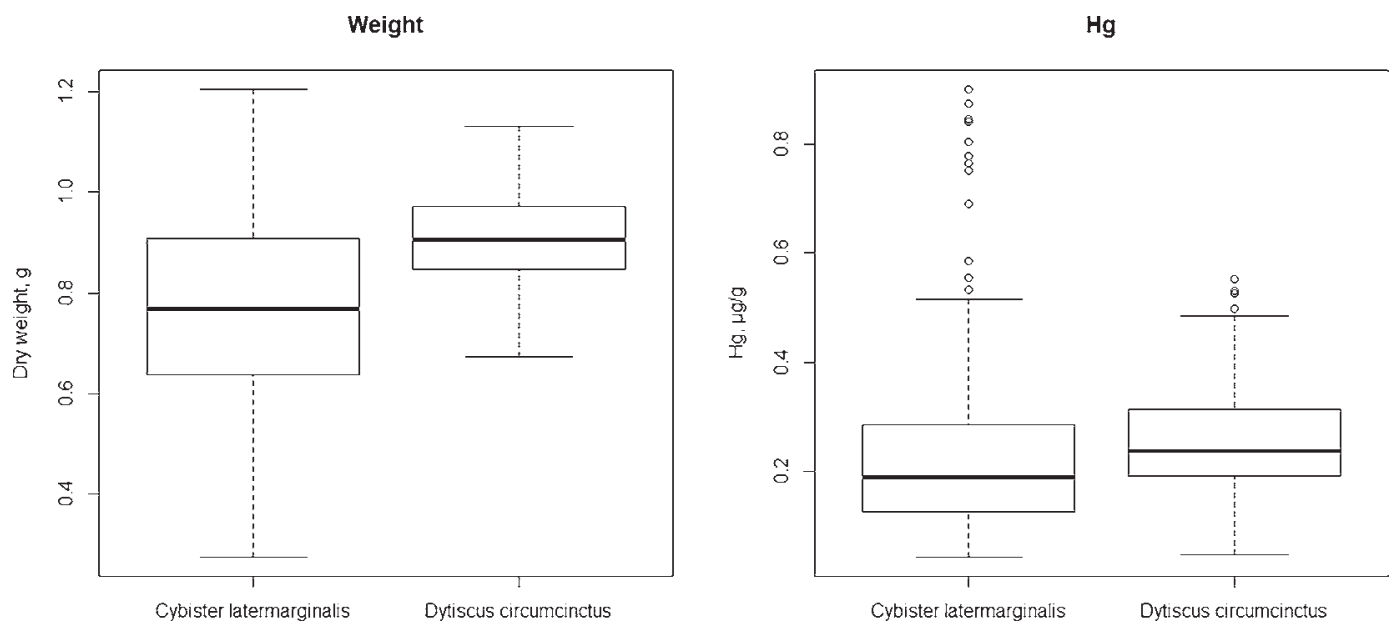

Fig. 1. Average dry weight of the beetles and average mercury concentration $(\mathrm{Hg})$ in the studied species (median; IQR; observable minimum and maximum; outliers).

Рис. 1. Средний сухой вес жуков (Weight), и общая концентрация ртути $(\mathrm{Hg})$ в изученных видах (медиана; межквартильный размах; наблюдаемые минимум и максимум; выбросы). 
Table 2. Statistical parameters of dry weight distribution $(\mathrm{g})$, concentration $(\mu \mathrm{g} / \mathrm{g})$, and average mercury contain per specimen $(\mu \mathrm{g})$

Таблица 2. Статистические параметры распределения сухой биомассы $(\mathrm{g})$, концентрации $(\mu \mathrm{g} / \mathrm{g})$, и общего содержания ртути в одной особи $(\mu \mathrm{g})$

\begin{tabular}{|c|c|c|c|c|}
\hline \multirow{3}{*}{ Statistical parameters } & \multicolumn{4}{|c|}{ Species } \\
\hline & \multicolumn{2}{|c|}{ C. lateralimarginalis } & \multicolumn{2}{|c|}{ D. circumcinctus } \\
\hline & 오오 & $0^{7} 0^{7}$ & pop & $0^{7} 0^{7}$ \\
\hline Number of specimens $(n)$ & 168 & 100 & 48 & 80 \\
\hline \multicolumn{5}{|c|}{ Dry weight, $g$} \\
\hline Min, $g$ & 0.413 & 0.275 & 0.796 & 0.673 \\
\hline Max, $g$ & 1.205 & 0.969 & 1.132 & 1.069 \\
\hline Average $\pm \mathrm{SD}, \mathrm{g}$ & $0.851 \pm 0.161$ & $0.631 \pm 0.136$ & $0.968 \pm 0.084$ & $0.879 \pm 0.075$ \\
\hline $\mathrm{CV}, \%$ & 18.8 & 21.6 & 8.7 & 8.5 \\
\hline \multicolumn{5}{|c|}{$\mathrm{Hg}, \mu \mathrm{g} / \mathrm{g}$} \\
\hline Min, $\mu \mathrm{g} / \mathrm{g}$ & 0.043 & 0.045 & 0.049 & 0.138 \\
\hline Max, $\mu \mathrm{g} / \mathrm{g}$ & 0.900 & 0.841 & 0.478 & 0.552 \\
\hline Average $\pm \mathrm{SD}, \mu \mathrm{g} / \mathrm{g}$ & $0.232 \pm 0.152$ & $0.221 \pm 0.154$ & $0.243 \pm 0.091$ & $0.265 \pm 0.096$ \\
\hline Median, $\mu \mathrm{g} / \mathrm{g}$ & 0.190 & 0.181 & 0.232 & 0.243 \\
\hline $\mathrm{CV}, \%$ & 65.4 & 69.5 & 37.3 & 36.1 \\
\hline \multicolumn{5}{|c|}{$\mathrm{Hg}, \mu \mathrm{g}$} \\
\hline Min, $\mu \mathrm{g}$ & 0.019 & 0.023 & 0.052 & 0.111 \\
\hline Max, $\mu \mathrm{g}$ & 0.683 & 0.640 & 0.496 & 0.493 \\
\hline Average $\pm \mathrm{SD}, \mu \mathrm{g}$ & $0.202 \pm 0.139$ & $0.143 \pm 0.111$ & $0.234 \pm 0.087$ & $0.231 \pm 0.080$ \\
\hline Median, $\mu \mathrm{g}$ & 0.162 & 0.113 & 0.238 & 0.214 \\
\hline $\mathrm{CV}, \%$ & 68.8 & 77.9 & 37.2 & 34.5 \\
\hline
\end{tabular}

and males than in D. circumcinctus (Table 2). This is also true for males and females separately.

The average mercury concentrations in body parts decline in the following order: meso-, metathorax, and abdomen $>$ legs $>$ head and prothorax $>$ elytra and wings (Table 2). The mercury concentrations in the legs and meso-, metathorax, and abdomen do not differ significantly whilst the mercury concentrations in head and prothorax significantly different from the concentrations in the elytra and wings. The mercury concentrations in body parts significantly positively correlate with each other $(r=0.51-0.95 ; p<0.05)$. The mercury concentrations in males of both species differ in all body parts, while differences in females are present only in the elytra and wings.
Although the mercury concentrations in females are higher than in males in both species, there are no significant differences (Table 2; Fig. 4). Nevertheless, the mercury concentrations in female specimens of $D$. circumcinctus are significantly lower in the legs and higher in the wings and elytra $(Z=-2.82, p=0.004$ and $\mathrm{Z}=3.23 ; \mathrm{p}=0.001$ ).

Significant differences of the average mercury concentrations are found only between female morphs of $D$. circumcinctus: the mercury concentrations in smooth females are significantly higher than in sulcate ones $(\mathrm{Z}=-2.47, \mathrm{p}=0.012$ ) (Fig. 3), which is determined by the higher concentration in meso-, metathorax, and abdomen $(Z=2.79, p=0.004)$, but there are no significant differences in other body parts.
Cybister latermarginalis

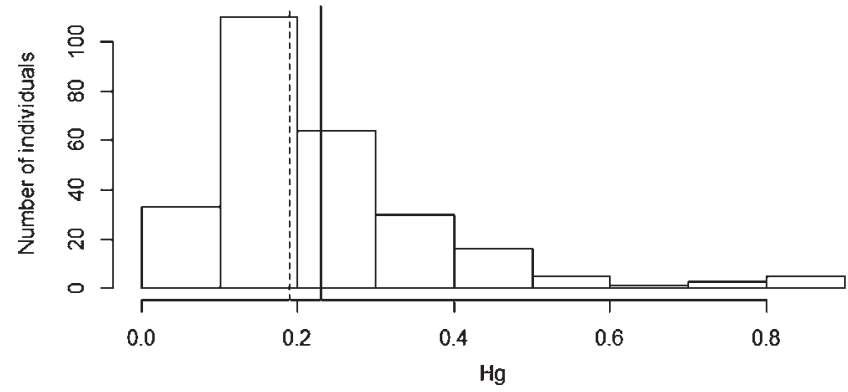

Dytiscus circumcinctus

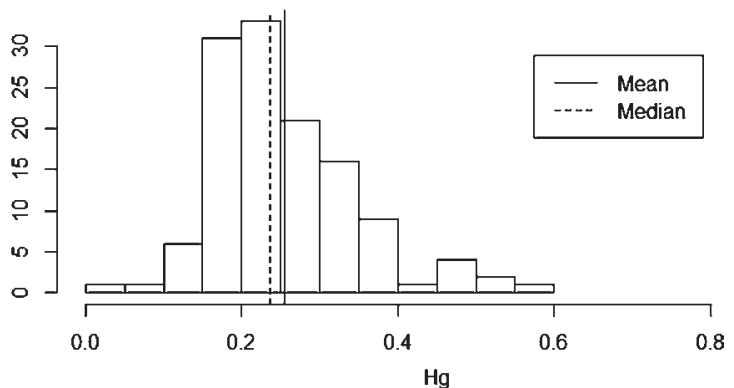

Fig. 2. Histogram of mercury concentrations in the studied species.

Рис. 2. Гистограмма распределения концентрации ртути для изученных видов. 
Table 3. Mercury concentrations in different body parts of studied species Таблица 3. Содержание ртути в различных частях тела изученных видов

\begin{tabular}{|c|c|c|c|c|c|c|}
\hline \multirow[b]{2}{*}{ Species } & \multirow[b]{2}{*}{ Sex } & \multirow[b]{2}{*}{$n$} & \multicolumn{4}{|c|}{$\mathrm{Hg}, \mu \mathrm{g} / \mathrm{g}$} \\
\hline & & & $\begin{array}{l}\text { Elytra and } \\
\text { wings }\end{array}$ & $\begin{array}{l}\text { Head and } \\
\text { prothorax }\end{array}$ & Legs & $\begin{array}{c}\text { Meso-, } \\
\text { metathorax, and } \\
\text { abdomen }\end{array}$ \\
\hline \multirow{2}{*}{$\begin{array}{l}\text { C. laterali- } \\
\text { marginalis }\end{array}$} & 90 & 167 & $\frac{0.091 \pm 0.060^{A}}{0.014-0.394}$ & $\frac{0.176 \pm 0.118^{\mathrm{B}}}{0.024-0.739}$ & $\frac{0.253 \pm 0.188^{\mathrm{C}}}{0.039-1.124}$ & $\frac{0.282 \pm 0.190^{C}}{0.044-1.107}$ \\
\hline & $\sigma^{7} O^{7}$ & 100 & $\frac{0.092 \pm 0.053^{\mathrm{A}}}{0.001-0.380}$ & $\frac{0.166 \pm 0.107^{\mathrm{B}}}{0.030-0.619}$ & $\frac{0.218 \pm 0.166^{\mathrm{BC}}}{0.039-1.120}$ & $\frac{0.281 \pm 0.222^{\mathrm{C}}}{0.020-1.270}$ \\
\hline \multirow{2}{*}{$\begin{array}{l}\text { D. circum- } \\
\text { cinctus }\end{array}$} & 90 & 46 & $\frac{0.137 \pm 0.053^{\mathrm{A}}}{0.039-0.345}$ & $\frac{0.184 \pm 0.070^{\mathrm{B}}}{0.071-0.485}$ & $\frac{0.230 \pm 0.075^{\mathrm{C}}}{0.088-0.431}$ & $\frac{0.280 \pm 0.116^{C}}{0.032-0.615}$ \\
\hline & $0^{7} 0^{x}$ & 80 & $\frac{0.110 \pm 0.045^{\mathrm{A}}}{0.034-0.289}$ & $\frac{0.200 \pm 0.062^{\mathrm{B}}}{0.111-0.386}$ & $\frac{0.281 \pm 0.096^{\mathrm{C}}}{0.037-0.553}$ & $\frac{0.319 \pm 0.127^{C}}{0.160-0.756}$ \\
\hline
\end{tabular}

NOTE: above line is average \pm standard deviation, below line is the minimum and maximum values; $\mathrm{A}, \mathrm{B}$ and $\mathrm{C}$ indicate significant differences between body parts. P-value was estimated with permutational ANOVA, post-hoc comparisons were estimated using the permutational two-sample test with Bonferroni correction.

ПРИМЕЧАНИЯ: над чертой — среднее значение \pm стандартное отклонение; под чертой — минимальное и максимальное значения; А, В и С указывают на статистически значимые различия между частями тела. Значение р оценивали с помощью перестановочного дисперсионного анализа (PermANOVA); для апостериорных сравнений использовали парный перестановочный тест с поправкой Бонферрони.
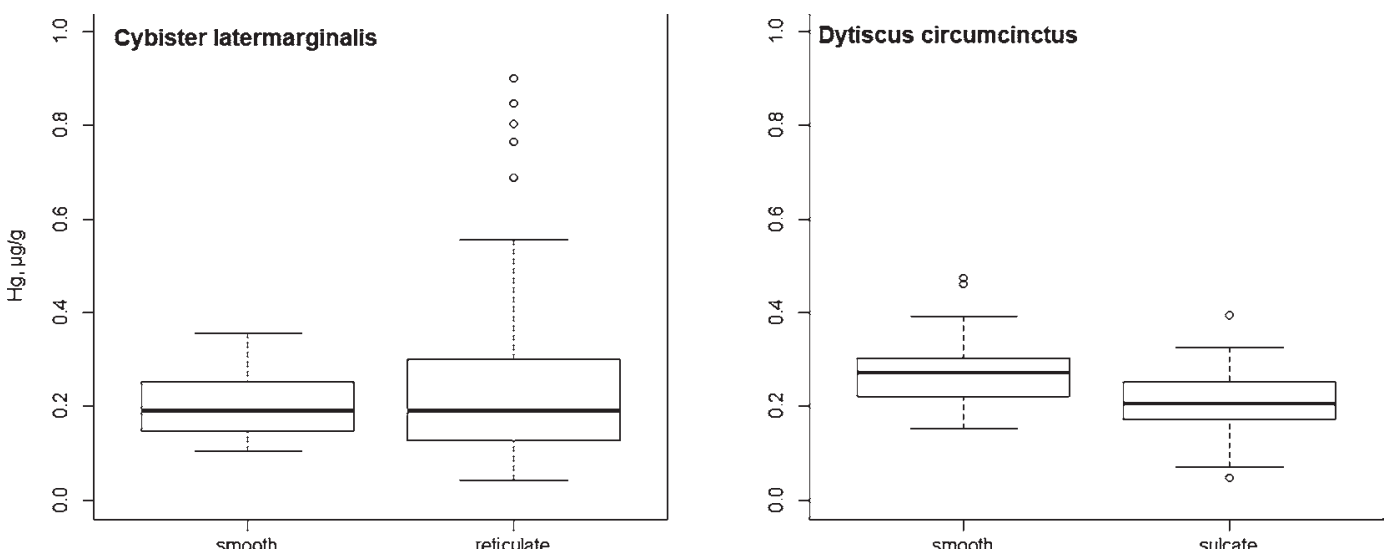

Fig. 3. Mercury concentrations in different female morphs of C. lateralimarginalis and D. circumcinctus. Designations as in Fig.1.

Рис. 3. Содержание ртути в разных морфах самок C. latermarginalis и D. circumcinctus. Обозначения как на Рис. 1.

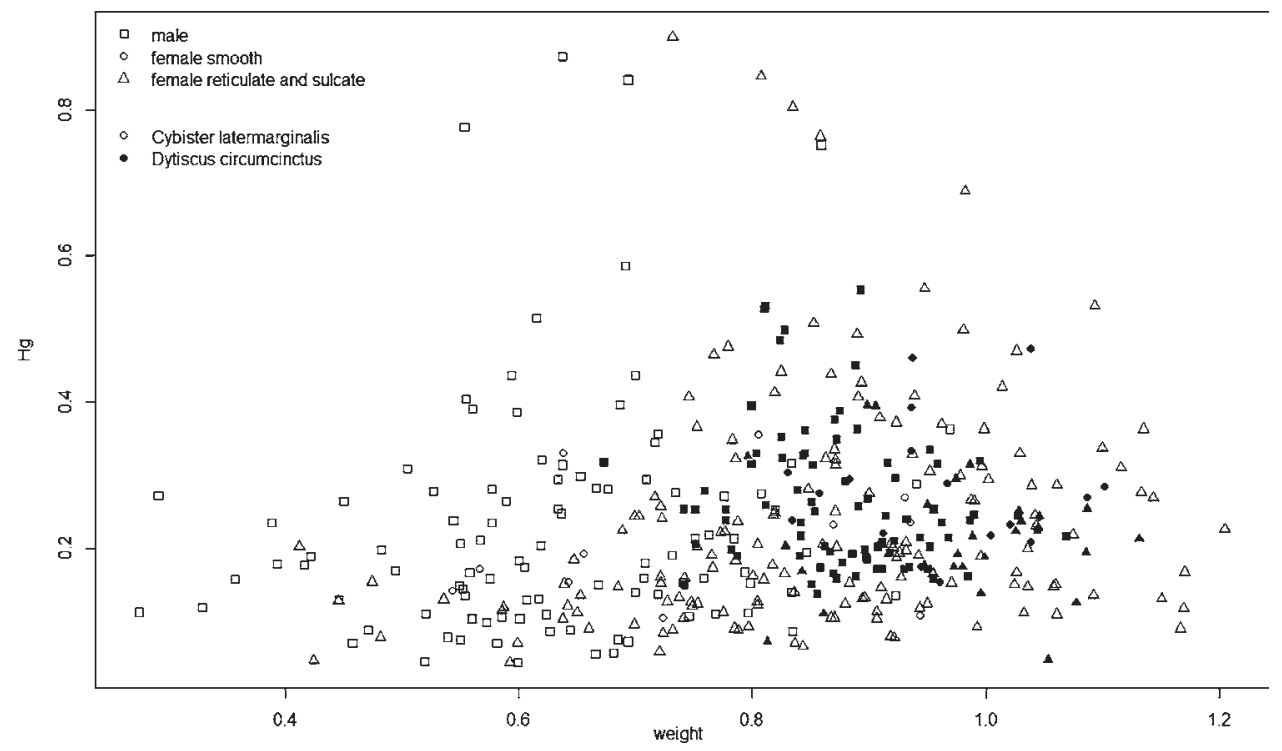

Fig. 4. Dependence between mercury concentrations and body weight

Рис. 4. Диаграмма зависимости концентрации ртути от массы тела. 
Permutational linear models indicate weak positive connection between the mercury concentration and the body weight in $C$. lateralimarginalis females (regression coefficient $b=0.2, p=0.011$ ), and weaker negative connection in D. circumcinctus males $(\mathrm{b}=-0.17, \mathrm{p}=0.048)$. The connection is not statistically significant in $C$. lateralimarginalis males and $D$. circumcinctus females.

\section{Discussion}

There are almost no data on the mercury content in predaceous beetles. It is known that the mercury content in beetles of the family Dytiscidae in California is 9-30 times as high as in with our samples and varies from 1.240 to $9.940 \mu \mathrm{g} / \mathrm{g}$ [Hothem et al., 2011]. In ground beetles Carabidae of the same region, mercury content was $2 / 3$ as high as in our samples, $0.134 \pm 0.157 \mu \mathrm{g} / \mathrm{g}$ [Ortiz et al., 2015]. In ground beetles in the Northwestern United States (Vermont), the mercury content was even lower, $0.048 \pm 0.067 \mu \mathrm{g} / \mathrm{g}$ [Rimmer et al., 2010].

The mercury concentrations in freshwater invertebrates of other taxonomic and ecological groups vary in different regions. At the coast of the Rybinsk Reservoir, the mercury concentrations in predaceous aquatic insects (Odonata larvae, true bugs Ilyocoris cimicoides (Linnaeus, 1758), Notonecta spp. and Gerris spp.), spiders Argyroneta aquatica (Clerck, 1757) and Dolomedes spp., and water mites Hydracarina spp. were close to the mercury concentrations in beetles of Lipetsk Oblast [Komov et al., 2017]. Freshwater gastropods of the same Oblast had a mercury concentration 1.5-2.0 times as high as in the beetles of our study [Komov et al., 2017]. True bugs of the genus Notonecta and beetles of the family Dytiscidae in California have the higher mercury concentrations $(1.180 \pm 0.08 \mu \mathrm{g} / \mathrm{g} \mathrm{d}$.w. $)$ than the beetles of our study [Ackerman et al., 2010]. Beetles of the family Hydrophilidae, which have predaceous larvae, of the estuaries off the coast of Portugal had an average mercury concentration $1.5-6$ times as high as in the beetles of Lipetsk Oblast [Tavares et al., 2008].

Mercury is distributed unevenly between organs and tissues. The mercury concentration in the crayfish Astacus leptodactylus (Eschscholtz, 1823) is the highest in muscles and lowest in the carapace [Lobus, 2009]. The mercury concentrations in freshwater fishes decline in the following order: liver $>$ muscles $>$ gills $>$ skeleton [Moiseenko, Gashkina, 2016].

The highest mercury concentrations in the abdomen are determined by the presence of digestive and reproductive organs, which accumulate mercury. High mercury concentrations in legs are determined by muscles, which have proteins that contain the $-\mathrm{SH}$ functional group of a thiol. This group has high chemical affinity to mercury [Nemova, 2004]. But the contribution of the mercury concentration in legs to the average mercury concentration in the body is minor, because the weight of the legs is only $9-13 \%$ of the average body weight of a beetle. The lowest mercury concentrations in the wings and elytra are determined by the high concentra- tion of chitin, which poorly accumulates mercury.

There is no agreement on which sex accumulates heavy metals more strongly. Possibly, different ecological and taxonomical groups of animals have sex differences in mechanisms of mercury accumulation. Acilius canaliculatus (Nicolai, 1822) and Dytiscus marginalis (Linnaeus, 1758) males had higher coefficients of accumulation of heavy metals ( $\mathrm{Mn}, \mathrm{Zn}, \mathrm{Cu}, \mathrm{Co}$, and $\mathrm{Pb}$ ) than females in the Voronezh Nature Reserve [Zhulidov, Emetz, 1981]. Those authors explained it by the differences in biogeochemical roles of the sexes, e.g., in the biogenic migration of elements and potential mechanisms of the protection of developing eggs in females. Mercury concentrations did not show significant differences between sexes in the 17-year cicada Magicicada cassini (Fisher, 1851), with different dry weights in specimens of both sexes [Heckel, Keener, 2007].

Males of the predaceous diving beetles of Lipetsk Oblast show the higher difference in median values of species than females, which agrees with the study of Zhulidov \& Emetz [1981] on the sex differences in accumulation of heavy metals. It is noteworthy that the significant differences in the mercury concentrations of different female morphs were shown in D. circumcinctus, which has morphs that differ in morphology more than in the other species. The difference in the mercury accumulation of different female morphs was determined by the metal concentrations in the meso-, metathorax, and abdomen. The meso- and metathorax contain powerful muscles that perform the synchronized movements of the swimming middle- and fore-legs in both sexes; the abdomen contains reproductive organs, including development of eggs in females. Therefore, it is likely that the difference in the mercury accumulation of different female morphs is associated with the abdomen that contains developing eggs. The presence of different female morphs is likely a compromise between reproductive success and survival after mating both on the physiological and morphological levels.

Food is the main source of mercury in the bodies of animals. Organisms have low rates of mercury excretion, and it accumulates during the whole lifespan. It was shown on crayfish that molting in arthropods plays no role in mercury excretion from the body, because its concentration in the exuvium is low [Lobus, 2009]. It is very likely that mercury accumulation in beetles begins at the larval stage, and mercury is not excreted from the body during the pupal stage. This idea agrees with the fact that nitrogen isotopic composition almost does not change during ontogeny in beetles, and small changes in carbon isotopic composition is associated with changes in the weight fraction of the fat tissue during metamorphosis at the pupal stage [Tsurikov et al., 2015].

The broad range of a set of data in the mercury concentration of $C$. lateralimarginalis in comparison with $D$. circumcinctus is probably associated with the varied diet of the former species. This more varied diet of $C$. lateralimarginalis in comparison with $D$. circumcinctus can play a role in the current expansion of the species range to the north. 
Large predaceous diving beetles are often harmed by the fishing in lakes in winter, where they fall into traps at the water surface while rising there to replenish the oxygen in their subelytral cavity [Egorov, 2016; Prokin et al., 2018]. Our results show that these diving beetles can be a valuable source of knowledge about the population structure of species and specifics of accumulation of different elements, including heavy metals.

Acknowledgements. The work of Yu.G. Udodenko and E.S. Ivanova was supported by the Russian Foundation for Basic Research (project No. 18-34-00569). The work of A.A. Prokin and D.G. Seleznev was supported by the Russian State Assignment (project no. AAAA-A18-118012690105-0).

\section{References}

Ackerman J.T., Miles A.K., Eagles-Smith C.A. 2010. Invertebrate mercury bioaccumulation in permanent, seasonal, and flooded rice wetlands within California's Central Valley// Science of the Total Environment. Vol.408. Iss.3. P.666-671.

Arnott S.E., Jackson A., Alarie Y. 2006. Distribution and potential effects of water beetles in lakes recovering from acidification // Journal of the North American Benthological Society. Vol.25. No.4. P.811-824.

Bergsten J., Töyrä A., Nilsson A.N. 2001. Intraspecific variation and intersexual correlation in secondary sexual characters of three diving beetles (Coleoptera: Dytiscidae) // Biological Journal of Linnean Society. Vol.73. Iss.2. P.221-232.

Cohen J. 1988. Statistical power analysis for the behavioral sciences. Second Edition. New York: Lawrence Erlbaum Associates Publishers. 567 pp.

Egorov L.V. 2016. Some data concerning the Coleoptera fauna of the Nature Reserve "Prisursky". Report 4 // Naychnye trudy gosudarstvennogo prirodnogo zapovednika "Prisursky". Vol.31. P.69-114.

Fitzgerald W.F., Lamborg C.H. 2007. Geochemistry of mercury in the environment // H.D. Holland, K.K. Turekian (Eds). Treatise on geochemistry. Vol.9. P.1-47.

Heckel P.F., Keener T.C. 2007. Sex differences noted in mercury bioaccumulation in Magicicada cassini // Chemosphere. Vol.69. No.1. P.79-81.

Hollander M., Wolfe D.A. 1999. Nonparametric Statistical Methods. Second Edition. New York: John Wiley \& Sons. 816 pp.

Hothem R.L., Rytuba J.J., Goldstein D., Brussee B. 2011. Mercury contamination from ine and natural sources in Harley Gulch, downstream from the Abbott and Turkey Run ercury Mines, Lake County, California // American Geophysical Union Fall Meeting Abstracts. P.576-578.

Komov V.T., Gremyachikh V.A., Udodenko Yu.G., Shchedrova Ye.V., Yelizarov M.Ye. 2017. [Mercury in abiotic and biotic components of aquatic and terrestrial ecosystems in the urban settlement on the shore of the Rybinsk reservoir] // Trudy instituta biologii vnutrennikh vod RAN. No.77(80). P.57-76 [in Russian].
Litovkin S.V, Sazhnev A.S. 2016. [New data on the distribution and biology of water beetles (Coleoptera: Haliplidae, Dytiscidae, Helophoridae, Georissidae, Hydrophilidae, Limnichidae, Curculionidae) in Russia] // Euroasian Entomological Journal. Vol.15. No.1. P.17-24 [in Russian, with English summary].

Lobus N.V. 2009. [The role of coat changing in the process of extracting mercury from the organism of the crawfish Astacus leptodactylus L. at its chronic uptake with feed] // Toksikologicheskij vestnik. No 4. P.22-24. [in Russian].

Mergler D., Anderson H.A., Chan L.H.M., Mahaffey K.R., Murray M., Sakamoto M., Stern A.H. 2007. Methylmercury exposure and health effects in humans: a worldwide concern // Ambio. Vol.36. No.1. P.3-11.

Moiseenko T.I., Gashkina N.A. 2016. Bioaccumulation of mercury in fish as indicator of water pollution // Geochemistry International. No.6. P.485-493.

Nemova N.N. [Biochemical effects of mercury accumulation in fish] Moscow: Nauka. 315 pp. [In Russian]

Ortiz Jr. C., Weiss-Penzias P.S., Fork S., Flegal A.R. 2015. Total and Monomethyl Mercury in Terrestrial Arthropods from the Central California Coast // Bulletin of Environmental Contamination and Toxicology. Vol.94. Iss.4. P.425-430.

Prokin A., Cherevichko A. 2017. Naturalisation of Cybister lateralimarginalis in the north of European Russia confirmed by the finding of larva // Latissimus. No.40. P.18-19.

Prokin A.A., Zemlyanukhin A.I., Seleznev D.G. 2018. Damage to diving beetles (Dytiscidae) from willow traps in Lipetsk oblast (Russia) and features of Cybister lateralimarginalis and Dytiscus circumcinctus populations in winter // Russian Entomological Journal. Vol.27. No.1. P.11-14.

Rice K.M., Walker E.M., Jr., Wu M., Gillette C., Blough E.R. 2014. Environmental mercury and its toxic effects // Journal of Preventive Medicine \& Public Health. Vol.47. No.2. P.74-83.

Rimmer C.C., Miller E.K., McFarland K.P., Taylor R.J., Faccio S.D. 2010. Mercury bioaccumulation and trophic transfer in the terrestrial food web of a montane forest // Ecotoxicology. No.19. P.697-709.

Selin N.E. 2009. Global Biogeochemical Cycling of Mercury: a review // Annual Review of Environment and Resources. Vol.34. P.43-63.

Scheuhammer A., Braune B., Chan H.M., Frouin H., Krey A., Letcher R., Loseto L., Noel M., Ostertag S., Ross P., Waylamd M. 2015. Recent progress on our understanding of the biological effects of mercury in fish and wildlife in the Canadian Arctic // Science of the Total Environment. Vol.509-510. P.91-103.

Tavares P.C., Kelly A., Maia R., Lopes R.J., Serrão Santos R., Pereira M.E., et al. 2008. Variation in the mobilization of mercury into Black-winged Stilt Himantopus himantopus chicks in coastal saltpans, as revealed by stable isotopes // Estuary, Coastal and Shelf Science. Vol.77. No.1. P.65-76.

Tsurikov S.M., Goncharov A.A., Tiunov A.V. 2015. Intra-body variation and ontogenetic changes in the isotopic composition $\left({ }^{13} \mathrm{C} /{ }^{12} \mathrm{C}\right.$ and $\left.{ }^{15} \mathrm{~N} /{ }^{14} \mathrm{~N}\right)$ of beetles (Coleoptera) // Entomological Review. Vol.95. No.3. P.326-333.

Zhulidov A.V., Emetz V. M. 1981. On the sex differences in heavy metal accumulation of water beetles // Zhurnal Obshchey Biologii. Vol.62. No.4. P.583-585. 